\title{
Article \\ Morphological and Molecular Characterization of Proliferative Inflammatory Atrophy in Canine Prostatic Samples
}

\author{
Giovana de Godoy Fernandes ${ }^{1,+}{ }^{+}$, Bruna Pedrina ${ }^{1,+}+{ }^{+}$, Patrícia de Faria Lainetti ${ }^{1}$, Priscila Emiko Kobayashi ${ }^{1}$, \\ Verônica Mollica Govoni ${ }^{1}$, Chiara Palmieri ${ }^{2}{ }^{(\mathbb{C}}$, Veridiana Maria Brianezi Dignani de Moura ${ }^{3}{ }^{(0)}$, \\ Renée Laufer-Amorim ${ }^{1}\left[\right.$ and Carlos Eduardo Fonseca-Alves ${ }^{1,4, *}$
}

check for updates

Citation: de Godoy Fernandes, G.; Pedrina, B.; de Faria Lainetti, P.; Kobayashi, P.E.; Govoni, V.M.; Palmieri, C.; de Moura, V.M.B.D.; Laufer-Amorim, R.; Fonseca-Alves, C.E. Morphological and Molecular Characterization of Proliferative Inflammatory Atrophy in Canine Prostatic Samples. Cancers 2021, 13, 1887. https://doi.org/10.3390/ cancers13081887

Academic Editors: José I. López and Kazutoshi Fujita

Received: 18 March 2021

Accepted: 9 April 2021

Published: 14 April 2021

Publisher's Note: MDPI stays neutral with regard to jurisdictional claims in published maps and institutional affiliations.

Copyright: (c) 2021 by the authors. Licensee MDPI, Basel, Switzerland. This article is an open access article distributed under the terms and conditions of the Creative Commons Attribution (CC BY) license (https:/ / creativecommons.org/licenses/by/ $4.0 /)$.
1 School of Veterinary Medicine and Animal Science, São Paulo State University_UNESP, Botucatu 18618-681, Brazil; giovana.godoy@unesp.br (G.d.G.F.); bruna.pedrina@unesp.br (B.P.); patricia.lainetti@unesp.br (P.d.F.L.); priscila.e.kobayashi@unesp.br (P.E.K.); veronica.m.govoni@unesp.br (V.M.G.); renee.laufer-amorim@unesp.br (R.L.-A.)

2 Gatton Campus, School of Veterinary Science, The University of Queensland, Gatton, QLD 4343, Australia; c.palmieri@uq.edu.au

3 School of Veterinary Medicine and Animal Science, Federal University of Goiás, Goiânia 18531-883, Brazil; vdmoura@ufg.br

4 Institute of Health Sciences, Paulista University-UNIP, Bauru 17048-290, Brazil

* Correspondence: carlos.e.alves@unesp.br

+ These authors contributed equally to this work.

Simple Summary: Prostatic diseases are important worldwide, being the prostate cancer (PC) the most common tumor in men. Among the factors associated with PC development, the preneoplastic lesions are well-recognized. Preneoplastic lesions are cellular morphological alterations, induced by different factors and present a potential to progression for PC. In this scenario, dogs are considered spontaneous models. Dogs naturally develops prostatic hyperplasia, preneoplastic lesions and PC. Among the preneoplastic lesions, the proliferative inflammatory atrophy (PIA) develops spontaneously in dogs. PIA is an epithelial lesion induced by prostatic chronic inflammation, leading to a proliferative atrophy of the prostate gland. Thus, this study aimed to perform a full PIA morphological, phenotypical and molecular characterization in dogs. After reviewing the archives of the veterinary pathology service, it was identified 171 dogs containing PIA in the prostate gland, and among the PC cases $(N=84)$, it was identified PIA lesions surrounding $60.7 \%$ of PC cases. Besides that, we identified loss of genes related to the maintenance of prostatic tissue and can predispose to malignant transformation. Moreover, mutations in androgen receptor gene were identified, demonstration alteration in DNA in PIA. Overall, these results support the hypothesis that PIA can be considered a preneoplastic lesion in canine prostate.

Abstract: Proliferative inflammatory atrophy (PIA) is an atrophic lesion of the prostate gland that occurs in men and dogs and is associated with a chronic inflammatory infiltrate. In this study, we retrospectively reviewed canine prostatic samples from intact dogs, identifying 50 normal prostates, 140 cases of prostatic hyperplasia, 171 cases of PIA, 84 with prostate cancer (PC), 14 with prostatic intraepithelial neoplasia (PIN) and 10 with bacterial prostatitis. PIA samples were then selected and classified according to the human classification. The presence of PIA lesions surrounding neoplastic areas was then evaluated to establish a morphological transition from normal to preneoplastic and neoplastic tissue. In addition, the expression of PTEN, P53, MDM2 and nuclear androgen receptor (AR) were analyzed in 20 normal samples and 20 PIA lesions by immunohistochemistry and qPCR. All PIA lesions showed variable degrees of mononuclear cell infiltration around the glands and simple atrophy was the most common histopathological feature. PIA was identified between normal glands and PC in 51 (61\%) out of the 84 PC samples. PIA lesions were diffusely positive for molecular weight cytokeratin (HMWC). Decreased PTEN and AR gene and protein expression was found in PIA compared to normal samples. Overall, our results strongly suggest that PIA is a frequent lesion associated with PC. Additionally, this finding corroborates the hypothesis that in dogs, as is the case in humans, PIA is a pre neoplastic lesion that has the potential to progress into PC, indicating an alternative mechanism of prostate cancer development in dogs. 
Keywords: dog; comparative oncology; inflammation; prostatic atrophy; preneoplastic lesion

\section{Introduction}

The contribution of inflammation to prostate carcinogenesis is well-known [1,2], occurring through a combination of repeated damage to the genome and increased cell proliferation [3]. The inflammatory process in the prostate gland is associated with a morphologically atrophic epithelium, characterized by a high proliferative index and decreased expression of apoptotic markers [1,3]. De Marzo et al. [4] proposed the term proliferative inflammatory atrophy (PIA) to designate the discrete focus of glandular epithelial proliferation with the morphological appearance of simple atrophy, surrounded by variable degrees of inflammation.

In men, PIA occurs in the peripheral zone of the prostate gland, where prostate cancer (PC) is also more commonly observed [4]. A mononuclear inflammatory infiltrate is frequently associated with PIA lesions [4-6] and these inflammatory cells secrete proteases, as well as mitogenic, antiapoptotic and angiogenic factors in the prostatic microenvironment [7], which ultimately induce epithelial cell atrophy, followed by cell proliferation $[5,8]$. PIA can occur adjacent to high-grade prostatic intraepithelial neoplasia (HGPIN) and prostate cancer (PC), with some studies highlighting the preneoplastic significance of PIA in human PC development $[9,10]$. The most accepted theory suggests a progression from PIA to HGPIN and subsequently PC [10,11]. De Marzo et al. [4] previously characterized the morphology and immunophenotype of PIA, describing $34 \%$ of focal atrophic lesions surrounding high-grade intraepithelial neoplasia (PIN), and thus, hypothesizing a morphological progression from PIA to HGPIN. PIA has been described in the canine prostate [12-16], although only from a morphological perspective, without analyzing its preneoplastic potential.

Chromosomal abnormalities were previously described in canine PIA lesions. Copy number gain was detected in CRYGS, ADIPOQ, SST genes and copy number losses were identified in CD38, ZNF518B, WDR1, SLC2A9 genes [16]. These results demonstrated the occurrence of chromosomal instability in canine PIA lesions and represent the first evidence of their premalignant potential. Loss of E-cadherin expression has also been reported in canine PIA [15]. Normally dividing prostatic epithelial cells can lose E-cadherin during cell division and re-express the same protein after the replication is completed [17]. Thus, all these previous studies suggest the occurrence of several genomic and protein alterations in canine PIA, that favors its potential preneoplastic lesion.

This study aimed to evaluate the immunophenotype of PIA lesions in dogs, establish a topographic relationship between normal, PIA and PC lesions, as well as to analyze TP53, MDM2, nuclear androgen receptor (AR) and PTEN protein and gene expression in PIA lesions, compared to normal prostates, in order to better characterize its preneoplastic potential in dogs.

\section{Results}

\subsection{Animal Demographic Data}

Prostate samples were collected from adult intact dogs of different ages and breeds. The group of dogs with normal prostate consisted of animals with a median age of 6 years (4-8 years), overrepresented by mixed breed dogs (30/50). Dogs with prostatic hyperplasia $(\mathrm{PH})$ had a median age of 9 years (6-12 years) and this group was also overrepresented by mixed breed dogs $(87 / 140)$. Among the pure breeds, the American pit bull terrier $(15 / 140)$ was the most affected. The median age of dogs diagnosed with PIA was 9 years (7-14 years), with mixed breed dogs being the most affected (95/171). PC-affected dogs had a median age of 11 years (9-16 years) with the highest prevalence in mixed breed dogs (21/84). The median age of dogs with PIN and bacterial prostatitis was 9 (7-10) and 7 (5-8) years, respectively. 


\subsection{Morphology and Immunophenotype of PIA}

All PIA lesions $(N=171)$ were surrounded by mononuclear cells, and specifically, by a low inflammatory infiltrate (Figure $1 \mathrm{~A}$ ) in $35.5 \%$ of samples $(61 / 171)$, moderate inflammation in $42.1 \%$ of samples (72/171) (Figure 1B) and severe inflammatory infiltrate in $22.4 \%$ (38/171) (Figure 1C). Simple atrophy was the most common histopathological feature, observed in $73 \%$ of all cases $(125 / 171)$. A mixed pattern was prevalent in $17.5 \%$ of cases $(30 / 171)$ and post atrophic hyperplasia $(\mathrm{PAH})$ in $9.5 \%(16 / 171)$.
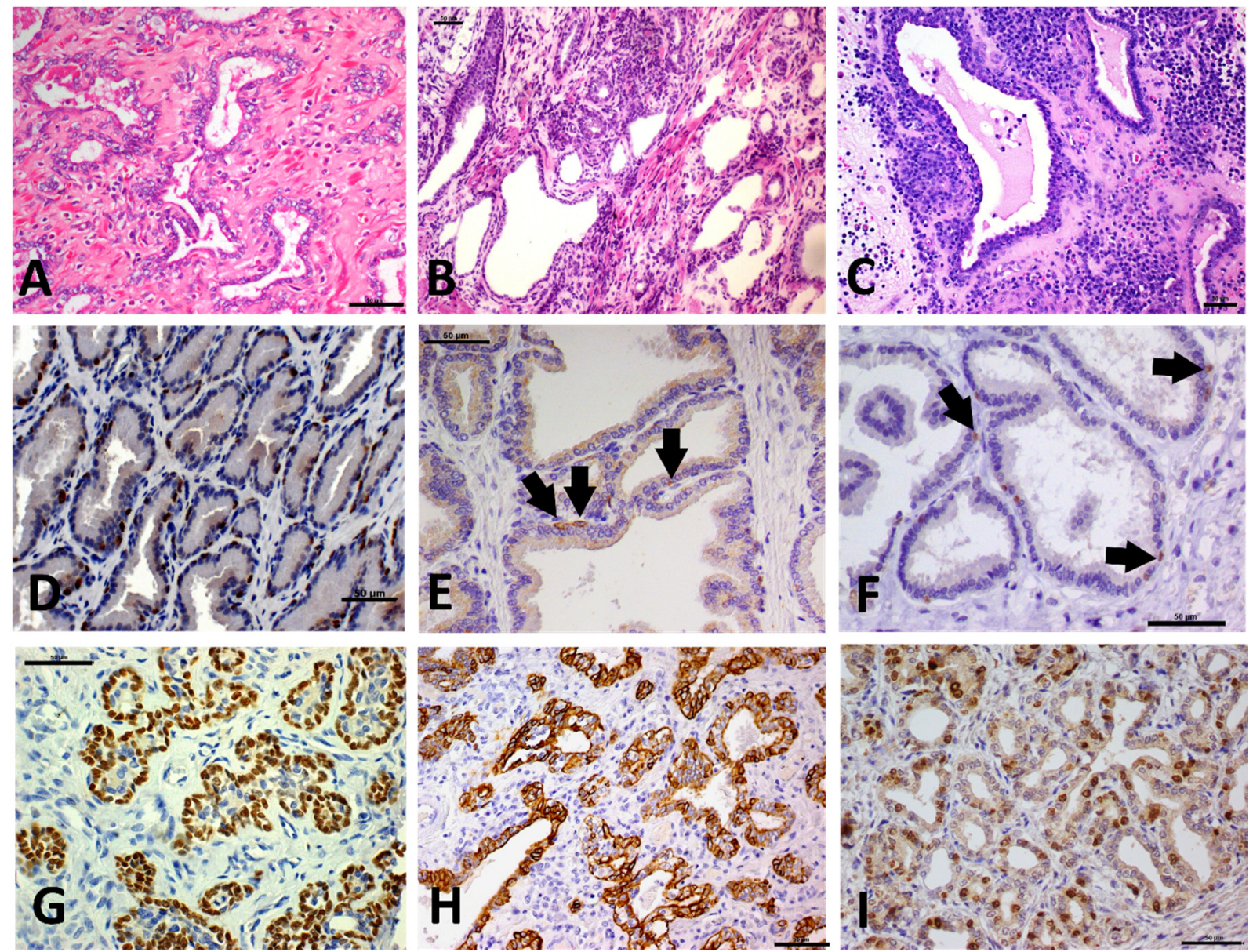

Figure 1. Hematoxylin and eosin (H\&E) staining and immunohistochemistry of canine prostate with proliferative inflammatory atrophy (PIA). (A): Discrete mononuclear inflammatory infiltrate admixed with multifocal atrophic glands with at least two layers of epithelial cells. (B): Moderate mononuclear inflammatory infiltrate and areas of prostatic gland atrophy with cells showing hyperchromatic nuclei and at least two layers of epithelial cells. (C): Severe mononuclear inflammatory infiltrate with atrophic epithelial cells showing at least two layers of epithelial cells, hyperchromatic nuclei and evident nucleolus. (D): Nuclear p63 expression in a normal prostate gland. There is a discontinuous basal cell layer. (E): High molecular wight cytokeratin expression by normal basal cells (arrows). (F): Nuclear Ki67 expression by normal basal cells (arrows). There is an absence of Ki67 in luminal epithelial cells and only scatted basal cells express Ki67. (G): Diffuse P63 expression by atrophic cells in a PIA. (H): Diffuse membranous expression of high molecular weight cytokeratin in a PIA. (I): Nuclear positive Ki67 expression by atrophic cells in a PIA lesion. Scale bar $=50 \mu \mathrm{m}$.

In normal prostatic tissue, high molecular weight cytokeratin (HMWC) (Figure 1D) and P63 (Figure 1E) were expressed by basal cells, showing a discontinuous layer $(100 \%-20 / 20)$. Interestingly, PIA lesions showed a continuous basal cell layer that was positive for P63 (Figure 1D) and HMWC (Figure 1E); with a score of four for both markers. The normal prostatic tissue had no Ki-67 expression in the epithelial luminal cells; only a few basal cells were Ki-67 positive (Figure 1F). The normal prostatic tissue had a mean of $2.2 \pm 1.5 \mathrm{Ki}-67$ positive cells, while PIA lesions (Figure 1I) showed a mean of $45.1 \pm 31.8 \mathrm{Ki}-67$ luminal 
and basal positive cells with a statistically significant difference between the two groups $(p<0.0001)$ Figure 2.

\section{$p<0.0001$}

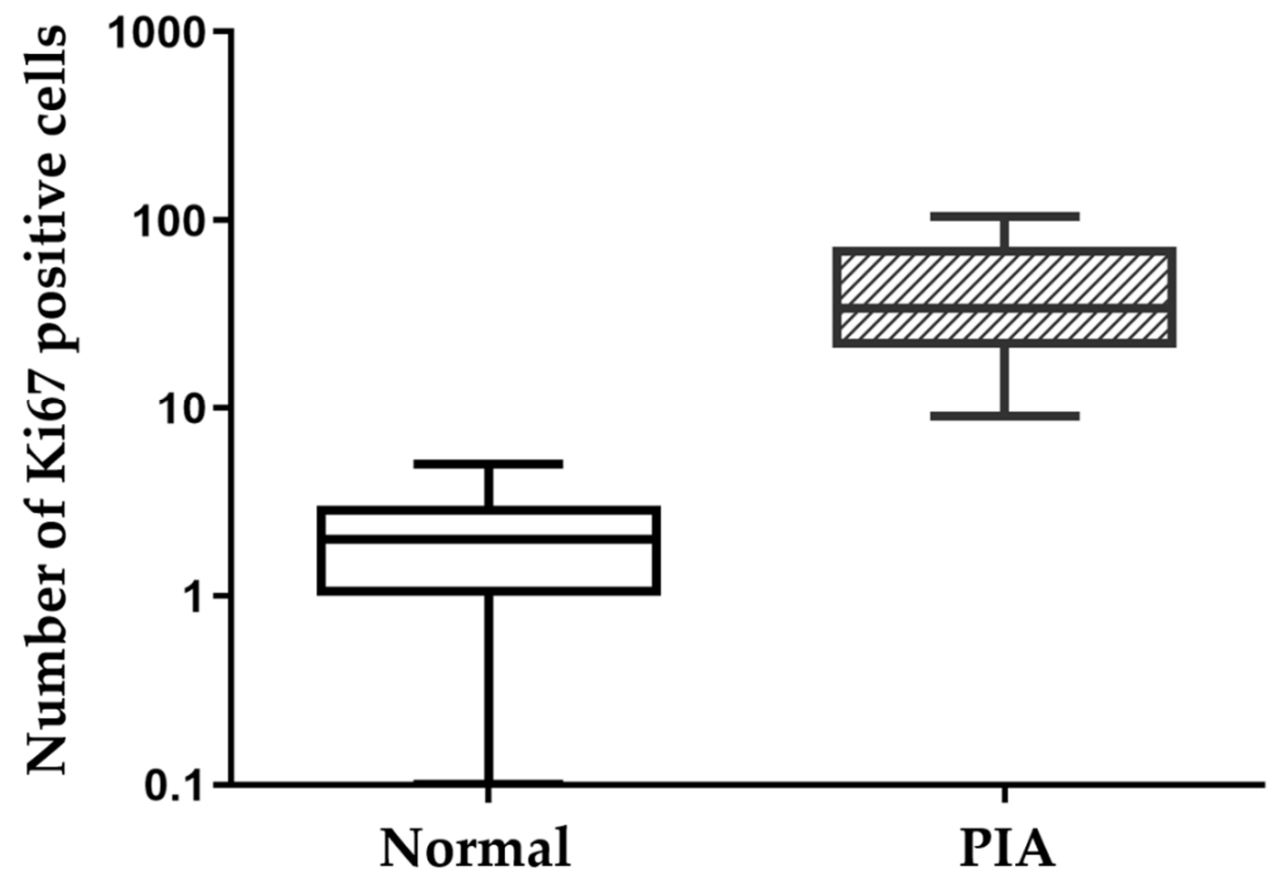

Figure 2. Ki67 protein expression in normal and proliferative inflammatory atrophy (PIA) samples. A high Ki67 index was observed in PIA compared to normal samples, indicating a high proliferative rate in PIA $(p<0.0001)$.

All samples with PIN (14/14) contained adjacent PIA lesions. No PIN foci were observed adjacent to PC lesions. A total of $61 \%(51 / 84)$ of the PC samples had PIA lesions close to the neoplastic areas and an evident histological transition from normal tissue (normal or hyperplastic) to PIA and PC was observed in 21.5\% (11/51) of the PC samples (Figure 3). 


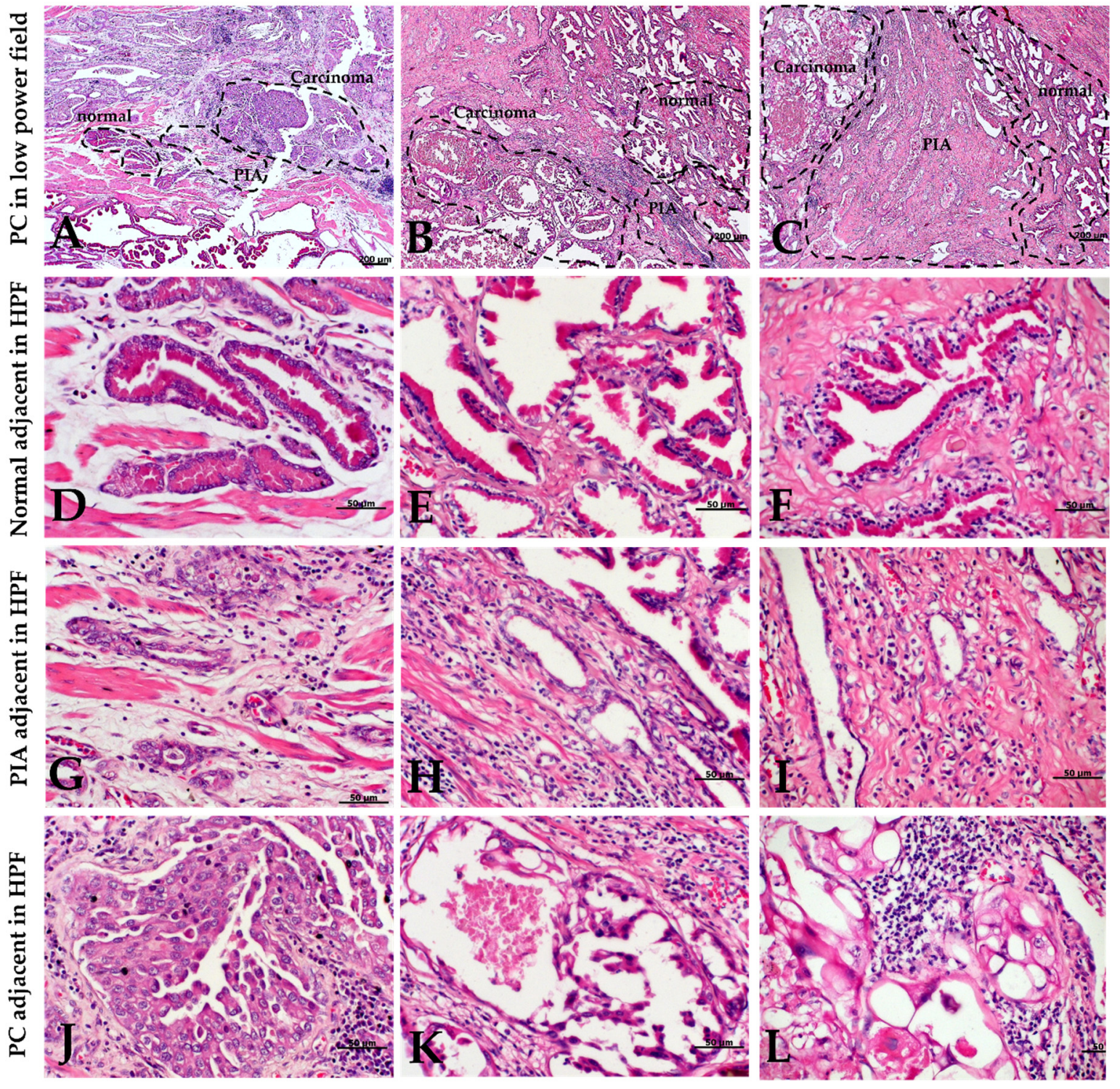

Figure 3. Hematoxylin and eosin (H\&E) staining from three different canine prostate carcinomas (PC). (A-C): Low power field containing a carcinoma area surrounded by PIA and a normal adjacent area. A clear morphological transition between normal, proliferative inflammatory atrophy (PIA) and PC areas is evident. (D-F): High power field (inset of figures (A-C), respectively) of adjacent normal tissue. Note the prostatic gland epithelium consisting of columnar and basal epithelial cells. (G-I): High power field of surrounding PIA (areas outlined by the plotted areas in figures (A-C)). Characteristic simple atrophy with one epithelial layer and hyperchromatic nuclei. (J-L): High power field of a carcinoma area. (J): Neoplastic cells disposed in nests and moderate pleomorphism. (K): Cells present a pseudopapillary shape with presence of degeneration. (L): Ballooning neoplastic cells showing degeneration associated intense surrounding inflammation. HPF: High power field.

\subsection{Immunohistochemical Features}

The immunohistochemical results are presented in Table 1. Both basal and luminal cells were p53 positive, with a nuclear and cytoplasmic expression pattern (Figure 4A). The p53 score was four in nine out of $20(45 \%)$ normal prostatic tissues and three in the remaining cases $(11 / 20)$. PIA samples were assigned a score of four in $40 \%$ of cases $(8 / 20)$, a score of three in $40 \%(8 / 20)$ and a score of two in $20 \%(4 / 20)$ (Figure $4 \mathrm{~B})$. There was no statistical difference in P53 scores between normal and PIA samples. PTEN expression was only observed in the nuclei and cytoplasm of luminal cells Figure 4C. All normal samples showed more than $75 \%$ of positive cells (score of four). Two PIA samples had a score of four, $25 \%(5 / 20)$ had a score of three, $25 \%(5 / 20)$ had a score of two and $40 \%(8 / 20)$ had 
a score of one (Figure 4D). We identified decreased staining in PIA samples compared to normal samples $(p=0.003)$. MDM2 was expressed in the nuclei of luminal and basal cells (Figure $4 \mathrm{E}$ ) of one normal sample (5\%) with a score of four, 30\% $(6 / 20)$ of samples with a score of three and $65 \%(13 / 20)$ with a score of two. Fifteen percent $(3 / 20)$ of PIA samples showed a score of four, $30 \%(6 / 20)$ showed a score of three and $55 \%(11 / 20)$ showed a score of two (Figure 4F). There was no statistical difference in MDM2 expression between normal and PIA samples.

Table 1. PTEN, P53, MDM2 and AR immunohistochemical expression in canine normal prostate and PIA samples.

\begin{tabular}{|c|c|c|c|c|c|c|}
\hline & \multicolumn{6}{|c|}{ Score } \\
\hline & Group & 1 & 2 & 3 & 4 & $p$ \\
\hline \multirow{2}{*}{ PTEN } & Normal & $0 \%(0 / 20)$ & $0 \%(0 / 20)$ & $0 \%(0 / 20)$ & $100 \%(20 / 20)$ & \multirow{2}{*}{$p=0.003$} \\
\hline & PIA & $40 \%(8 / 20)$ & $25 \%(5 / 20)$ & $25 \%(5 / 20)$ & $10 \%(2 / 20)$ & \\
\hline \multirow{2}{*}{ P53 } & Normal & $0 \%(0 / 20)$ & $0 \%(0 / 20)$ & $55 \%(11 / 20)$ & $45 \%(9 / 20)$ & \multirow{2}{*}{$p=0.3568$} \\
\hline & PIA & $0 \%(0 / 20)$ & $20 \%(4 / 20)$ & $40 \%(8 / 20)$ & $40 \%(8 / 20)$ & \\
\hline \multirow[b]{2}{*}{ MDM2 } & Normal & $0 \%(0 / 20)$ & $65 \%(13 / 20)$ & $30 \%(6 / 20)$ & $5 \%(1 / 20)$ & \multirow{2}{*}{$p=0.5784$} \\
\hline & PIA & $0 \%(0 / 20)$ & $55 \%(11 / 20)$ & $30 \%(6 / 20)$ & $15 \%(3 / 20)$ & \\
\hline \multirow{2}{*}{ AR } & Normal & $0 \%(0 / 20)$ & $0 \%(0 / 20)$ & $0 \%(0 / 20)$ & $100 \%(20 / 20)$ & \multirow{2}{*}{$p=0.01$} \\
\hline & PIA & $0 \%(0 / 20)$ & $45 \%(9 / 20)$ & $55 \%(11 / 20)$ & $0 \%(0 / 20)$ & \\
\hline
\end{tabular}

Legend: Score $1=11-25 \%$ positive cells; score $2=26-50 \%$ positive cells; score $3=51-75 \%$ positive cells; score $4=$ more than $75 \%$ positive cells.

AR was positive in luminal cells and occasionally in basal cells (Figure 4G). All normal prostate samples (20/20) showed more than $75 \%$ AR-positive cells. The expression pattern was significantly decreased in PIA samples compared to normal samples $(p=0.01)$. Fiftyfive percent $(11 / 20)$ of PIA samples showed a score of three and $45 \%(9 / 20)$ had a score of two (Figure $4 \mathrm{H})$.

\subsection{Gene Expression}

There was no difference in TP53 and MDM2 transcript levels between normal and PIA samples $(p>0.05)$. A positive correlation between TP53 and MDM2 transcript levels in normal $(\mathrm{R}=0.7754 ; p<0.0001)$ and PIA $(\mathrm{R}=0.6573 ; p=0.0202)$ samples was observed, suggesting that in both cases the increased TP53 transcript level is correlated with a simultaneous increased expression of MDM2 (Supplementary Figure S1). No statistical correlations were observed between the remaining comparisons.

PTEN $(P=0.0307)$ and $A R(P=0.0008)$ expression was decreased in PIA compared to normal samples (Figure 5). The median relative quantification (RQ) of $A R$ in normal samples was 1.8 (0.3-9), while in PIA samples it was $0.7 \pm 0.1-1.6$. The median PTEN RQ was $1.4 \pm 0.3-6.7$ and $0.7 \pm 0.2-3$ in normal and PIA samples, respectively. 



Figure 4. Immunohistochemical staining of the normal canine prostate and canine proliferative inflammatory atrophy (PIA). (A): PTEN expression in a canine normal sample: nuclear and cytoplasmic positive staining of luminal epithelial cells. (B): PTEN expression in proliferative inflammatory (PIA) samples: atrophic prostatic luminal cells with a lack of PTEN expression. (C): Nuclear and cytoplasmic P53 expression in a normal canine prostatic sample and (D): PIA lesions. (E,F): Positive cytoplasmic and nuclear MDM2 expression in normal (E) and PIA (F) samples. (G,H): nuclear androgen receptor (AR) expression in a normal prostatic sample and lack of expression in PIA samples (H). Counterstaining with Harris hematoxylin, DAB, 20×. 
A

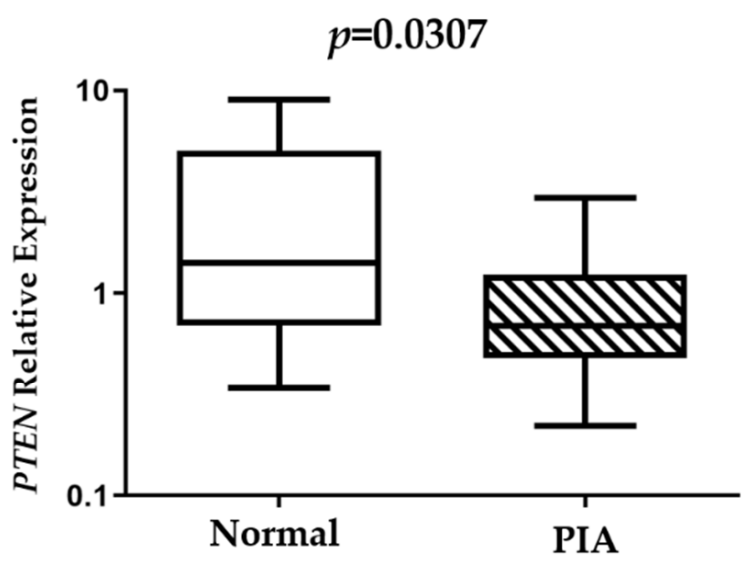

C

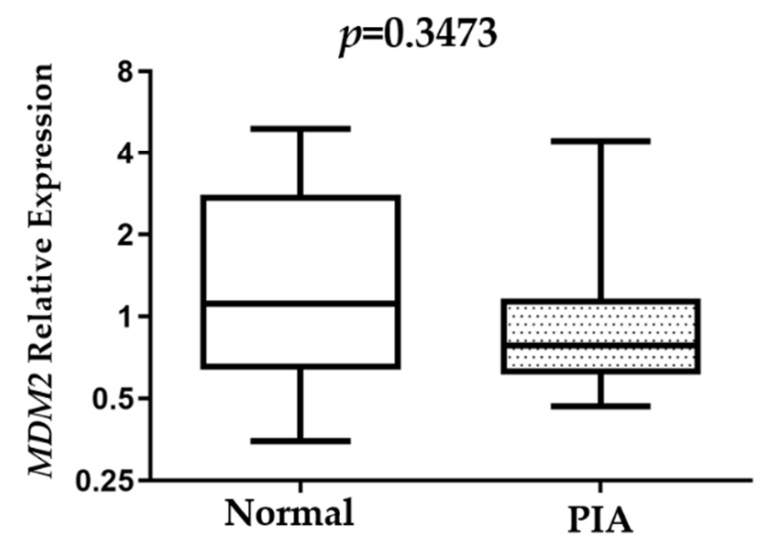

B

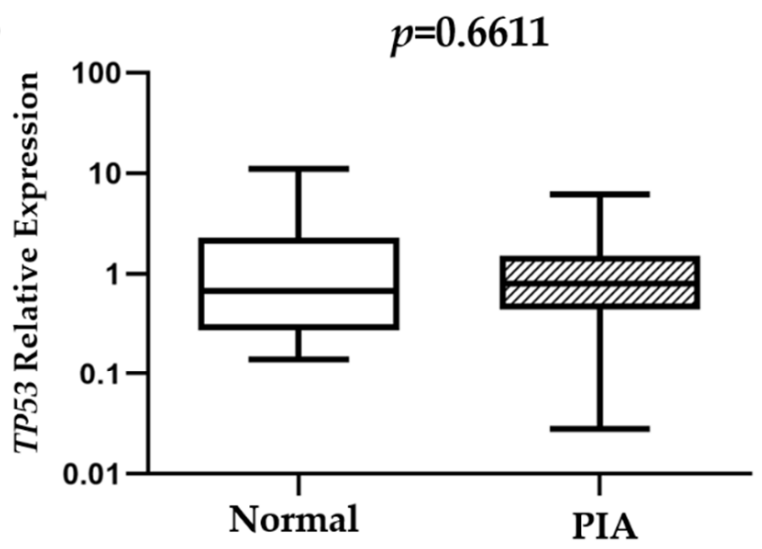

D

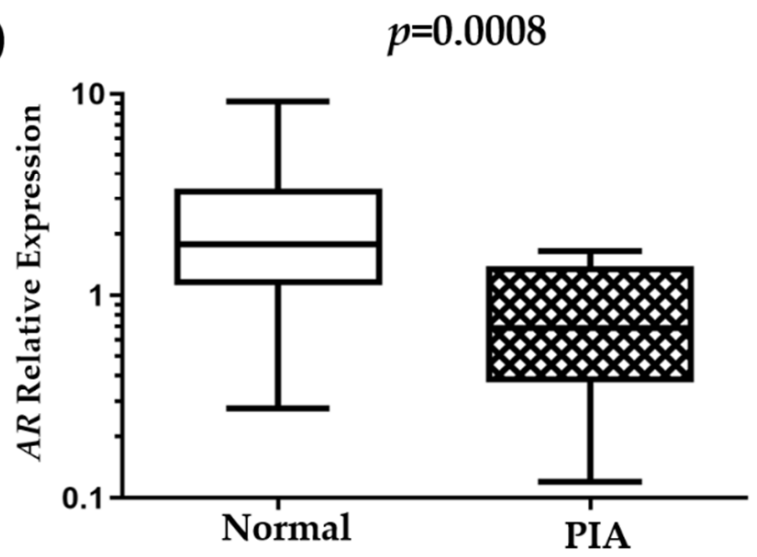

Figure 5. Evaluation of PTEN, TP53, MDM2 and AR gene expression in normal compared to proliferative inflammatory atrophy (PIA) samples. (A) Decreased PTEN expression was observed in PIA samples compared to normal samples (A). TP53 (B) and MDM2 (C) transcripts showed no statistically significant differences. AR expression decreased in PIA samples compared to normal samples (D).

\subsection{Matrix of Multiple Correlation}

Using a matrix of multiple correlation among PTEN, P53, MDM2 and AR genes and proteins, a positive strong correlation was demonstrated between PTEN and MDM2 gene expression (Spearman $\mathrm{r}=0.6$ ) and between $A R$ and $M D M 2$ gene expression. The matrix of multiple correlation did not show a positive correlation with the respective gene and protein expression (Figure 6). 


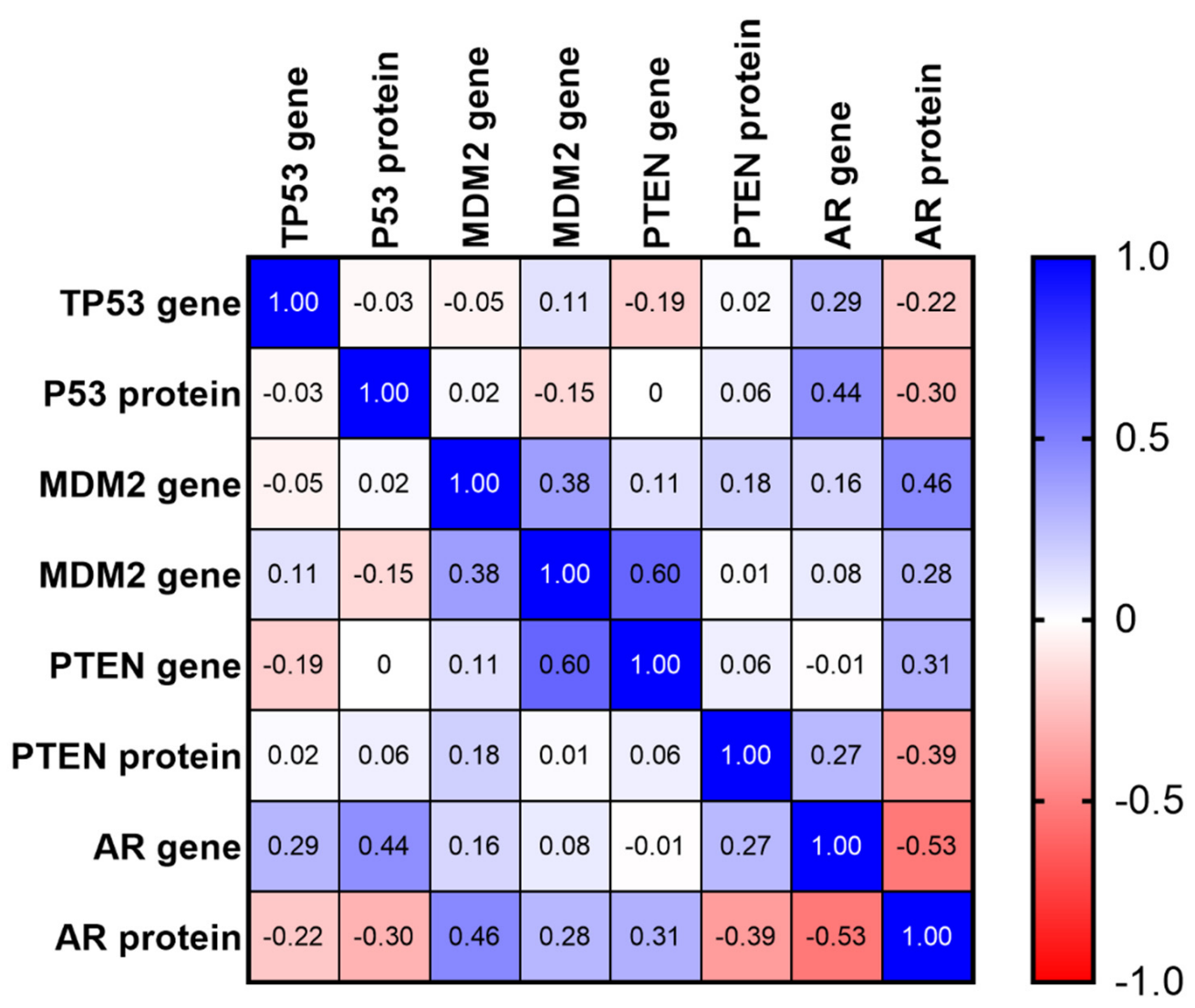

Figure 6. Matrix of multiple correlation among PTEN, TP53, MDM2 and AR gene and protein expression. The red color represents negative correlation and the blue color represents a positive correlation. The color intensity is associated with a strongest correlation. The blue color represents a positive correlation and the red color represents a negative correlation.

\subsection{AR Sequencing}

All samples were amplified in PCR analysis in the electrophoresis. However, after sequencing, eight out of 20 samples showed a very low sequencing quality and were excluded from the alignment analysis. In the PIA samples aligned in the investigation of $A R$ mutations $(N=12)$, six out of 12 samples (50\%) showed mutations, with one sample showing several nucleotide alterations (Figure 7). 


\section{A}

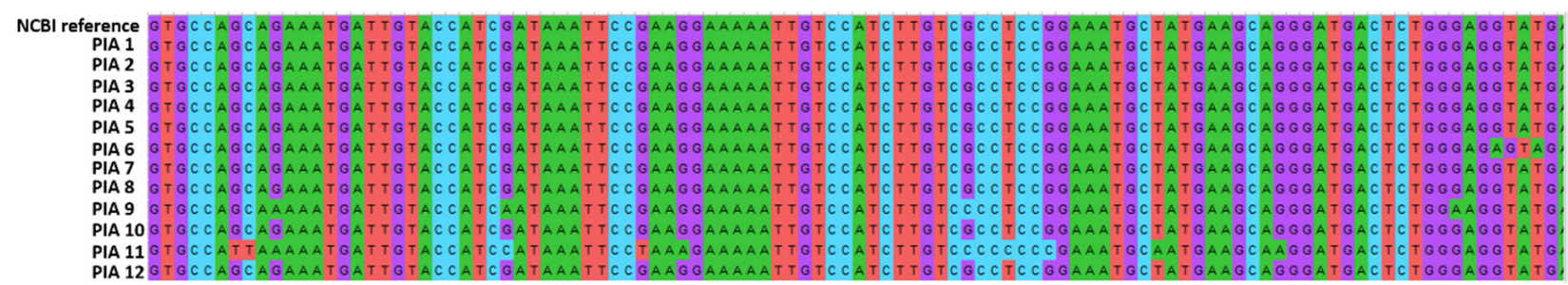

B

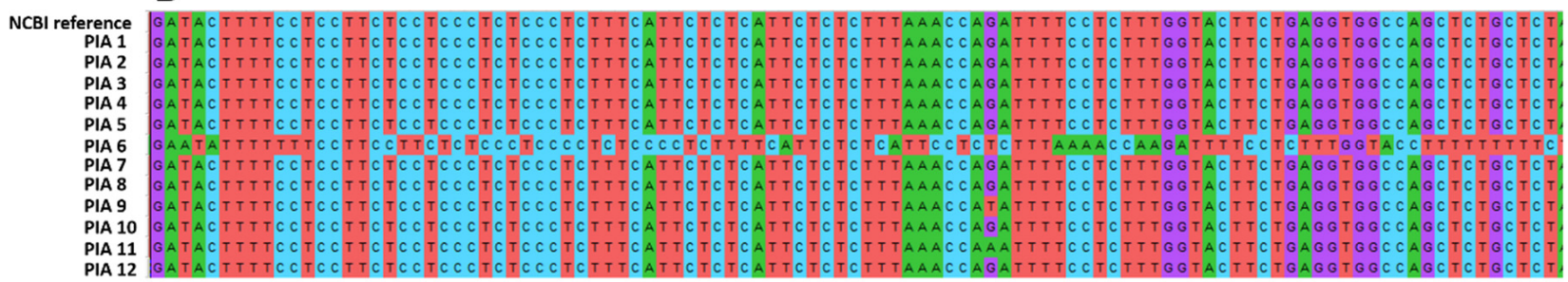

C

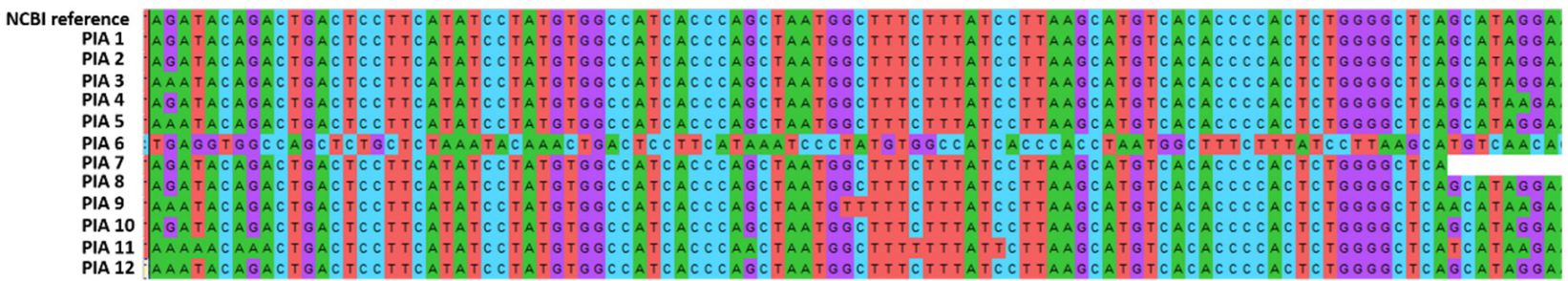

Figure 7. Androgen receptor (AR) sequencing analysis of the 12 proliferative inflammatory atrophy (PIA) samples after alignment. Each figure $(\mathrm{A}-\mathrm{C})$ represents different regions of the AR gene alignment. There are six samples containing mutations, with PIA 6 representing the samples with a higher number of nucleotide modification. (A,B): sequencing alignment showing mutations in PIA6, PIA9 and PIA 11 samples. C: Sequencing alignment evidencing mutation in the samples PIA3, PIA4, PIA5, PIA6, PIA9, PIA11.

\section{Discussion}

In human PC, the progression of PIA to high grade-PIN (HGPIN) and PC cancer has been described over recent years, due the role of chronic inflammation in cancer development [1-6]. In dogs, little is known in regard to the carcinogenic process and the progression of preneoplastic lesions to PC. It seems that canine PC develops from androgen-independent cells and most cases of canine PC have been found to be negative for AR [16]. Thus, alterations to the AR receptor are considered to be one of the most important steps in PC development. The previously published literature has focused on studying PIA as a preneoplastic lesion and has shown copy number variations, indicating molecular instability [16]. Although an increased number of studies have been published in recent years, the carcinogenic process of canine PC development is still unclear.

Based on this gap in the literature, our results suggest that PIA is a very common histological lesion in the prostates of intact dogs, with a prevalence of $36.5 \%$ in our dataset. On the other side, PIN was present in only $3 \%$ of selected cases (14/469). The real incidence of PIN lesions in the canine prostate is controversial. Waters and Bostwick [18,19] reported an incidence of 55-65\%, while in two larger studies conducted by Aquilina et al. [20] and Madewell et al. [21], the incidence was low (less than 3\%) without any histological association between PIN and PC [20,21]. Thus, PIN lesions have been most likely overestimated or not correctly diagnosed on histological sections and their role in canine prostatic carcinogenesis is still unknown.

The studied population was based on intact dogs, because in Brazil, castration of male dogs is not routinely performed due to cultural factors. Interestingly, we did not see the frequent occurrence of prostate cancer in castrated dogs. This is important in studies 
evaluating PIA, because castrated dogs show atrophy of the prostate during hormone deprivation and present hormonal atrophy instead of an inflammatory atypical atrophy.

PIA is a common finding in the canine prostate, although its pathogenesis, mechanisms of occurrence and role on prostatic carcinogenesis are unclear. PIA lesions surrounded canine PC areas in $61 \%$ of carcinoma samples and, in $21.5 \%$ of these cases, the morphological transition between benign tissue, PIA lesions and invasive prostate cancer was evident. Taking into account previously published articles assessing the molecular basis of canine PIA, in addition to the findings from the present study, this result may suggest a potential association between PIA and PC. The morphological transition term was previously introduced by Wang et al. [22] to associate PIA as a preneoplastic lesion in human prostatic pathology. Morphological transition refers to normal, followed by PIA areas colliding to prostatic carcinoma in histological specimens. In our samples, PIA lesions were characterized by a higher proliferative index (shown by Ki67) compared to normal prostates, underlining their high proliferative potential. Previously, our research group investigated the proliferative index of 12 PIA and 18 PC samples, demonstrating a median Ki67 expression level of 54.5 and 366, respectively [23]. Ki67 expression is higher in PIA and PC compared to normal samples. In the carcinogenic process of the human prostate, a dynamic progression from low-PIN, to HGPIN, and finally PC is widely accepted [5,24]. De Marzo et al. [4] then identified PIA lesions as a new precursor of HGPIN. Thus, the carcinogenic process of human and canine prostates might occur through different, a yet unexplored, mechanisms.

Canine PC is characterized by a heterogeneous pattern of cytokeratin expression, as attested by the consensus reached on the intermediate phenotype (luminal markers+ / basal markers + ) of canine PC [12,13,25-27]. As evidenced in this study, intermediate cells are also found in greater quantities in PIA lesions, similar to the prevalent cell population of PIA in humans. It is likely that, even in dogs, PIA lesions arise from the proliferation of basal cells stimulated by the inflammatory environment. During normal prostate development and differentiation, basal cells proliferate, reducing the expression of basal cells markers (CK5, HMWC and P63) and overexpressing luminal markers (CK18), until they completely lack the basal cell markers and express luminal markers only [28]. Due to the high proliferative index of PIA lesions, demonstrated by the expression of Ki67, it is most likely that cells are constantly stimulated to divide without further developing into luminal cells. Interestingly, many canine PCs show an intermediate phenotype (concomitant expression of P63 or CK5 or CK8/18) $[13,27,29]$. Thus, the same cell phenotype may be involved in the development of both PIA and PC in dogs and both lesions may have a common origin in most-but not all-cases.

PTEN, P53, MDM2 and AR dysregulation in human prostate cancer has been widely described [30-32]. PTEN and P53 downregulation plays an important role in cell growth and apoptosis [33]. Furthermore, TP53 and MDM2 genes play a dual role during cell proliferation: $M D M 2$ is an oncogene associated with the proliferation of prostatic cells and TP53 acts as an MDM2 inhibitor [30]. During PC progression, tumor cells become androgenindependent and the AR inhibition of human prostate cells promotes cell migration and invasiveness [34].

P53 and MDM2 protein expression were similar in normal prostates and PIA, although a positive correlation between TP53 and MDM2 transcript levels in both cases was observed, i.e., higher TP53 transcripts had higher MDM2 levels. This correlation could suggest a role of MDM2 in controlling TP53 transcripts, as is the case in the human prostate [35]. TP53 and MDM2 expression have been widely studied in human cancers and MDM2 is a negative regulator of the TP53 transcript [35-37]. In canine PC, upregulation of MDM2 and downregulation of TP53 transcript levels have previously been described [38]. Recently, TP53 copy number loss and MDM2 gains were described in canine PC, suggesting that P53 and MDM2 could be important drivers in canine prostatic carcinogenesis [16]. Since P53 and MDM2 were not deregulated in PIA samples, and both markers have instead been de- 
scribed as altered in PC [16,38], P53 downregulation and MDM2 overexpression may occur only in the advanced stage of prostatic carcinogenesis, after malignant transformation.

Our results show downregulation of the AR gene and protein levels in PIA samples, as compared to normal prostate samples. The $A R$ gene has a key role in prostatic development and maintenance [39]. In dogs, downregulation of the $A R$ gene is common in PC development [39]. Previously, our research group demonstrated an $A R$ copy number loss in canine PC [16], indicating $A R$ loss as an important event in canine PC development. Since we demonstrated the downregulation of $A R$, this gene may be altered in the early stages of neoplastic development and this result supports the hypothesis of the potential progression from PIA to PC. The lack of $A R$ expression in canine PC has been widely demonstrated in previous studies [16,25-27,38]. Additionally, our results have demonstrated that PIA with AR downregulation may be a precursor lesion to PC. Together, this information reinforces the idea of PIA progression into invasive PC in dogs. However, since we demonstrated an intermediate phenotype for PIA lesions, the AR downregulation may occur due the cell differentiation from basal cells into luminal cells. Thus, this result should be evaluated carefully.

Another gene undergoing downregulation in PIA lesions is PTEN. In human PC, PTEN loss is correlated with PC androgen independence [40]. PTEN downregulation is associated with decreased AR levels and these alterations are associated with activation of the anti-apoptotic pathway [40,41]. In knockout PTEN mice (Pten+/-), used as models of prostate carcinogenesis, the animals developed spontaneous inflammation with a high number of preneoplastic lesions and carcinomas compared to the controls [42]. Thus, PTEN loss is likely important during the carcinogenic process of the prostate gland [42].

Mice are the classical animal models used for studying the development of PIN and PC [43]. However, even though they may experience high-grade inflammation, PIA cannot be induced in these experimental models [42]. Thus, dogs represent a unique opportunity for comparative studies in order to evaluate the role of PIA as preneoplastic lesions in the prostate.

The high proliferative index and the downregulation of PTEN and AR in PIA lesions may reflect their preneoplastic potential. The PIA premalignant potential is strongly supported by the high mutation index identified in our sequencing analysis. A total of six out of 12 samples (50\%) showed mutations, and canine PC is strongly associated with AR decreased expression (even in castrated dogs). Thus, mutations in the AR gene can lead to the progression of PIA to PC in intact dogs.

\section{Materials and Methods}

\subsection{Animals and Experimental Design}

This study was performed in accordance with the National and International Recommendations for the Care and Use of Animals (National Research Council) [44]. All procedures have been approved by the Ethics Committee on Animal Use (CEUA) of the Veterinary Teaching Hospital of São Paulo State University (CEUA/UNESP, \#0208/2016). All samples were obtained from Brazilian dogs.

\subsection{Tissue Selection}

Four hundred and sixty nine hematoxylin and eosin (H\&E) slides from different canine prostates were selected from the Veterinary Pathology archive of São Paulo State University-UNESP, between 2011 and 2019. Histological evaluation of normal, PIN, and PC samples was performed according to the human WHO Tumors of the Urinary System and Male Genital Organs guidelines [45], which were recently adapted to canine PC [14]. PIA lesions were identified based on morphological features, as described by De Marzo et al. [4]. All samples were from adult intact dogs: 50 normal prostates, 140 prostatic hyperplasia, 171 proliferative inflammatory atrophy (PIA), 84 prostate carcinoma (PC), 14 prostatic intraepithelial neoplasia (PIN) and 10 bacterial prostatitis samples were 
obtained. The H\&E slides from the 84 PC cases were selected to evaluate PIA and PIN surrounding the neoplastic tissue, as previously described [22].

\subsection{PIA Morphological Features}

The intensity of inflammation was scored according to De Marzo et al. [4] with modifications. Briefly, all H\&E PIA slides $(N=171)$ were evaluated using a numerical scale from 0 to 6 , with 0 representing no inflammation, 1 and 2 mild inflammation, 3 and 4 moderate inflammation and 5 and 6 severe inflammation. The key morphological findings to identify PIA lesions in a low power field $(5 \times)$ were overall hyperchromatic appearance, associated inflammatory infiltrate, loss of papillary architecture and cuboidal cell morphology. In a higher power field, key findings were acini showing at least two layers of epithelial cell, atrophic appearance of cuboidal cells with scant cytoplasm, and in some cases, the presence of evident nucleolus and mitotic figures [4,12].

Lesions were divided into simple atrophy, $\mathrm{PAH}$ and mixed pattern (simple atrophy and PAH), according to De Marzo et al. [4]. The presence of dilated glands was also evaluated and referred to as cystic atrophy.

\subsection{Immunohistochemistry}

Twenty normal prostate samples and 20 PIA paraffin blocks were further selected to investigate both gene and protein expression of specific markers as outlined below. Immunohistochemistry for HMWC, P63, Ki67, PTEN, P53, MDM2 and androgen receptor (AR) was performed with antibodies that had been previously validated to cross-react with canine tissue samples [15,38]. Slide sections were dewaxed in xylol and rehydrated in graded ethanol. For antigen retrieval, the slides were incubated with citrate buffer ( $\mathrm{pH}$ 6.0) in a pressure cooker $\left(\mathrm{Pascal}^{\circledR}\right.$; Dako, Carpinteria, CA, USA). The slides were treated with freshly prepared $3 \%$ hydrogen peroxide in methanol for $20 \mathrm{~min}$ and further washed in Tris-buffered saline. The primary antibodies were diluted to 1:500 for PTEN (Bioss, Massachusets, USA -Bs-0686R), 1:50 for MDM2 (Abcam, Cambridge, UK-ab38618), 1:50 for P53 (Santa Cruz Biotecnology, sc-75366), 1:100 for AR (Abcam, Cambridge, UK-ab77557), 1:300 for HMWC (DakoCytomation, clone: 34ßE12), 1:100 for P63 (DakoCytomation, clone 4A4), 1:300 for Pan-cytokeratin (Invitrogen), 1:50 for Ki-67 (DakoCytomation, clone: MIB1) with an overnight incubation at $4{ }^{\circ} \mathrm{C}$. A polymer system (Envision, Dako, Carpinteria, CA, USA) was applied as a secondary antibody conjugated to peroxidase and $3^{\prime}$-diaminobenzidine tetrahydrochloride (DAB1, Dako, Carpinteria, CA, USA) was used as the chromogen, for $5 \mathrm{~min}$, followed by Harris hematoxylin counterstain.

Negative controls were performed for all antibodies by omitting the primary antibody, replacing them with Tris-buffered saline and also with an iso-type matched immunoglobulin according to Hewitt et al. [46]. Normal prostate was used as a positive control for AR, p63, HMWC and PTEN. A normal lymph node was used as a positive control for p53, MDM2 and Ki67 according to the Human Protein Atlas recommendation (www.proteinatlas.org, accessed on 15 November 2020).

\subsection{Immunohistochemical Score}

As regards P53, MDM2, AR, PTEN, P63 and HMWC, samples were scored based on the percentage of positive cells for each antibody with the following scores: $1-10 \%$ positive cells (score 0 ), $11-25 \%$ positive cells (score 1 ); $26-50 \%$ positive cells (score 2 ); $51-75 \%$ positive cells (score 3 ); and more than $76 \%$ positive cells (score 4 ). The immunohistochemical results were independently interpreted by three investigators (C.E.F.A., P.E.K. and R.L.A.) The distribution (basal or luminal cells) of P63 and HMWC was also evaluated. Ten high power fields were used to establish the final IHC score. Ki-67 analysis was made by counting the number of positive cells per total of 1000 cells. 


\subsection{Laser-Capture Microdissection and $q P C R$}

For mRNA extraction, microdissection was performed using a Leica AS LMD lasercapture system (Leica Microsystems, Wetslzar, Germany), according to [47] with modifications. mRNA analysis was performed with 20 normal and 20 PIA fresh frozen tissues (same animal prostates as those used for immunohistochemistry). Briefly, $10 \mu \mathrm{m}$ tissue sections were cut in a cryostat (Leica Microsystems) and mounted on Nuclease and Human Nucleic acid free PEN-membrane slides $2.0 \mu \mathrm{m}$ (MembraneSlides, Leica Microsystems). The slides were stained (H\&E) and once air-dried, PIA areas were microdissected [47]. mRNA was extracted with RNeasy Micro Kit (Qiagen, Hilden. Germany) according to the manufacturer instructions. cDNA was synthesized in a final volume of $20 \mu \mathrm{L}$, and each reaction contained $1 \mu \mathrm{g}$ of total RNA treated with DNAse I (Life Technologies, Rockville, MD, USA), $200 \mathrm{U}$ of SuperScript III reverse transcriptase (Life Technologies), $4 \mu \mathrm{L}$ of $5 \mathrm{X}$ SuperScript First-Strand Buffer, $1 \mu \mathrm{L}$ of each dNTP at $10 \mathrm{mM}$ (Life Technologies), $1 \mu \mathrm{L}$ of Oligo-(dT)18 (500 ng/ $\mu \mathrm{L}$ ) (Life Technologies), $1 \mu \mathrm{L}$ of random hexamers $(100 \mathrm{ng} / \mu \mathrm{L})$ (Life Technologies), and $1 \mu \mathrm{L}$ of 0.1 M DTT (Life Technologies). Reverse transcription was performed for $60 \mathrm{~min}$ at $50{ }^{\circ} \mathrm{C}$, and the enzyme was subsequently inactivated for $15 \mathrm{~min}$ at $70{ }^{\circ} \mathrm{C}$. cDNA was stored at $-80^{\circ} \mathrm{C}$.

TP53, MDM2, AR and PTEN and the endogenous genes (Table 2) were conducted in a total volume of $10 \mu \mathrm{L}$ containing Power SYBR Green PCR Master Mix (Applied Biosystems; Foster City, CA, USA), $1 \mu \mathrm{L}$ of cDNA (1:10) and $0.3 \mu \mathrm{M}$ of each primer. The reactions were performed in triplicate in 384-well plates using QuantStudio 12K Flex Thermal Cycler equipment (Applied Biosystems; Foster City, CA, USA). A dissociation curve was included in all experiments to determine the PCR product specificity. Relative gene expression was quantified using the 2- $\Delta \Delta \mathrm{CT}$ method [48].

Table 2. Forward and reverse primer sequence for each gene used in RT-qPCR analyses.

\begin{tabular}{|c|c|c|}
\hline Gene Symbol & Location & Primer Sequences \\
\hline$A R$ & Chromosome 24 & $\begin{array}{c}\text { F: 5'-CGCCCCTGACCTGGTTT-3' } \\
\text { R: } \text { 5'-GGCTGTACATCCGGGACTTG-3' }^{\prime}\end{array}$ \\
\hline PTEN & Chromosome 26 & $\begin{array}{c}\text { F: } 5^{\prime} \text {-CGACGGGAAGACAAGTTCATG-3' } \\
\text { R: } 5^{\prime} \text {-TCACCGCACACAGGCAAT-3' }\end{array}$ \\
\hline MDM2 & Chromosome 10 & $\begin{array}{l}\text { F: 5'-GGGCCCCTTCGTGAGAATTG-3' } \\
\text { R: 5'-GGTGTGGCTTTTCTCAGGGATT-3' }\end{array}$ \\
\hline TP53 & Chromosome 5 & $\begin{array}{c}\text { F: } 5^{\prime} \text {-GAACGCTGCTCTGACAGTAGTGA-3' } \\
\text { R: } 5^{\prime} \text {-CCCGCAAATTTCCTTCCA-3' }\end{array}$ \\
\hline$H P R T$ & Chromosome X & $\begin{array}{l}\text { F: 5'-AGCTTGCTGGTGAAAAGGAC-3' } \\
\text { R: 5'-TTATAGTCAAGGGCATATCC-3' }\end{array}$ \\
\hline
\end{tabular}

F: forward; R: reverse.

\subsection{DNA Extraction and Sequencing}

DNA extraction of 20 PIA tissues used in mRNA expression was performed using DNeasy Blood and Tissue Kits (Ambion, Life Technologies, MA, USA), according to manufacturer's instructions. The amplification of the androgen receptor (AR) DNA-binding domain was performed in a Veriti 96-Well Thermal Cycler (Thermo Fisher Scientific, MA, USA). The methodology was performed according to the previously described by RiveraCalderon et al. [49]. Briefly, $5 \mu \mathrm{L}$ of $10 \times$ PfuUltra II, $0.5 \mu \mathrm{L}$ of $100 \mu \mathrm{M}$ dNTP, $1 \mu \mathrm{L}$ of each oligonucleotide in $10 \mu \mathrm{M}$ of each primer, $1 \mu \mathrm{L}$ of genomic DNA $(100 \mathrm{ng} / \mu \mathrm{L})$ and $1 \mu \mathrm{L}$ PfuUltra II fusion HS DNA polymerase (Agilent, CA, USA). The primers used were previously published by Lai et al. [50].

After of the amplification, the AR DNA-binding domain was analyzed in $2 \%$ agarose gel stained with Neotaq Brilliant Plus DNA Stain (Neobio, Brazil). Then, the PCR products were cut from the agarose gel were and the DNA sequencing was evaluated with a BigDye ${ }^{\mathrm{TM}}$ Terminator v 3.1 Cycle Sequencing Kit version 3.1, according to the manufacturer's instructions (Applied Biosystems, Thermo Fisher Scientific, MA, USA). The RT-amplicons were directly sequenced at ABI 3500 (Applied Biosystems, Thermo Fisher Scientific, MA, USA). 
The resulting nucleotide sequences were compared to data of the NBCI (National Center for Biotechnology Information, Bethesda, MD, USA) (gi:6578766).

Sequences analysis was performed in the MEGA Software (www.megasoftware.net, accessed on 17 February 2021) [51], a FASTA analysis was performed, and the sequences aligned with the reference gene from NCBI (gi:6578766), according to the previous literature description [50]. Then, sequences with low quality were excluded.

\subsection{Data Analysis}

Statistical analyses were performed using GraphPad Prism v.5.0 (GraphPad Software Inc., La Jolla, CA, USA). Kruskal-Wallis or Mann-Whitney U tests was applied to compare TP53, MDM2, AR and PTEN transcription levels between normal and PIA samples. The chisquare exact test was used to evaluate difference in the immunohistochemical expression between normal and PIA samples.

\subsection{Data Availability}

The authors confirm that the data supporting the findings of this study are available within the article and/or its Supplementary Materials.

\section{Conclusions}

Canine PIA is a common lesion in the dog prostate and shares many morphological similarities with human PIA. Our results strongly suggest that PIA is a potential pre neoplastic lesion and is associated with the progression to PC.

Supplementary Materials: Supplementary materials can be found at https://www.mdpi.com/ article/10.3390/cancers13081887/s1. Figure S1. Canine prostate gland with atrophic lesion. The slides were stained with hematoxylin and eosin staining and tissue area with inflammatory atrophic gland were selected (A). Then, lase microdissection was performed to obtain only the epithelial portion of these atrophic glands (B). Hematoxylin and eosin staining, 200×.

Author Contributions: Conceptualization, G.d.G.F. and B.P.; methodology, G.d.G.F., B.P., P.E.K., P.d.F.L., C.E.F.-A.; software, V.M.G. and C.E.F.-A.; validation, C.E.F.-A. and R.L.-A.; formal analysis, G.d.G.F., B.P., P.E.K., V.M.B.D.d.M., C.P., R.L.-A., C.E.F.-A.; investigation, G.d.G.F., B.P., P.E.K. and C.E.F.-A.; resources, C.E.F.-A. and R.L.-A.; data curation, P.d.F.L. and C.E.F.-A.; writing-original draft preparation, G.d.G.F., B.P. and C.E.F.-A.; writing-review and editing, G.d.G.F., B.P., P.E.K., P.d.F.L., V.M.B.D.d.M., V.M.G., C.P., R.L.-A. and C.E.F.-A.; visualization, G.d.G.F., B.P., P.E.K., P.d.F.L., V.M.B.D.d.M., V.M.G., C.P., R.L.-A., C.E.F.-A.; supervision, C.E.F.-A.; project administration, C.E.F.-A. and R.L.-A.; funding acquisition, C.E.F.-A. All authors have read and agreed to the published version of the manuscript.

Funding: This research was funded by Sao Paulo Research Foundation (FAPESP), grants numbers \#2019/00497-9 and \#2012/18426-1.

Institutional Review Board Statement: The study was conducted according to the guidelines of the Declaration of Helsinki, and approved by the Ethics Committee of the Veterinary Teaching Hospital of São Paulo State University (CEUA/UNESP, \#0208/2016).

Informed Consent Statement: Not applicable.

Data Availability Statement: The data presented in this study are available in Supplementary Materials.

Acknowledgments: The authors would like to thank Marcio Carvalho for his help during q-PCR experiments. The content of this manuscript has been published in part of the thesis of Carlos Eduardo Fonseca Alves.

Conflicts of Interest: The authors declare no conflict of interest. The funders had no role in the design of the study; in the collection, analyses, or interpretation of data; in the writing of the manuscript, or in the decision to publish the results. 


\section{References}

1. Palapattu, G.S.; Sutcliffe, S.; Bastian, P.J.; Platz, E.A.; De Marzo, A.M.; Isaacs, W.B.; Nelson, W.G. Prostate carcinogenesis and inflammation: Emerging insights. Carcinogenesis 2005, 26, 1170-1181. [CrossRef]

2. de Bono, J.S.; Guo, C.; Gurel, B.; De Marzo, A.M.; Sfanos, K.S.; Mani, R.S.; Gil, J.; Drake, C.G.; Alimonti, A. Prostate carcinogenesis: Inflammatory storms. Nat. Rev. Cancer 2020, 20, 455-469. [CrossRef]

3. Montironi, R.; Mazzucchelli, R.; Lopez-Beltran, A.; Cheng, L.; Scarpelli, M. Mechanisms of disease: High-grade prostatic intraepithelial neoplasia and other proposed preneoplastic lesions in the prostate. Nat. Clin. Pract. Urol. 2007, 4, 321-332. [CrossRef]

4. De Marzo, A.M.; Marchi, V.L.; Epstein, J.I.; Nelson, W.G. Proliferative inflammatory atrophy of the prostate: Implications for prostatic carcinogenesis. Am. J. Pathol. 1999, 155, 1985-1992. [CrossRef]

5. De Marzo, A.M.; Platz, E.A.; Epstein, J.I.; Ali, T.; Billis, A.; Chan, T.Y.; Cheng, L.; Datta, M.; Egevad, L.; Ertoy-Baydar, D.; et al. A working group classification of focal prostate atrophy lesions. Am. J. Surg Pathol. 2006, 30, 1281-1291. [CrossRef] [PubMed]

6. Gao, Y.; Wei, L.; Wang, C.; Huang, Y.; Li, W.; Li, T.; Mo, C.; Qin, H.; Zhong, X.; Wang, Y.; et al. Chronic prostatitis alters the prostatic microenvironment and accelerates preneoplastic lesions in C57BL/6 mice. Biol. Res. 2019, 52, 30. [CrossRef] [PubMed]

7. Wang, W.; Bergh, A.; Damber, J.E. Cyclooxygenase-2 expression correlates with local chronic inflammation and tumor neovascularization in human prostate cancer. Clin. Cancer Res. 2005, 11, 3250-3256. [CrossRef] [PubMed]

8. Ashok, A.; Keener, R.; Rubenstein, M.; Stookey, S.; Bajpai, S.; Hicks, J.; Alme, A.K.; Drake, C.G.; Zheng, Q.; Trabzonlu, L.; et al. Consequences of interleukin $1 \beta$-triggered chronic inflammation in the mouse prostate gland: Altered architecture associated with prolonged CD4. Prostate 2019, 79, 732-745. [CrossRef]

9. Sugar, L.M. Inflammation and prostate cancer. Can. J. Urol. 2006, 13 (Suppl. 1), 46-47.

10. Karaivanov, M.; Todorova, K.; Kuzmanov, A.; Hayrabedyan, S. Quantitative immunohistochemical detection of the molecular expression patterns in proliferative inflammatory atrophy. J. Mol. Histol. 2007, 38, 1-11. [CrossRef]

11. De Marzo, A.M.; Platz, E.A.; Sutcliffe, S.; Xu, J.; Grönberg, H.; Drake, C.G.; Nakai, Y.; Isaacs, W.B.; Nelson, W.G. Inflammation in prostate carcinogenesis. Nat. Rev. Cancer 2007, 7, 256-269. [CrossRef]

12. Palmieri, C.; Story, M.; Lean, F.Z.X.; Akter, S.H.; Grieco, V.; De Marzo, A.M. Diagnostic Utility of Cytokeratin-5 for the Identification of Proliferative Inflammatory Atrophy in the Canine Prostate. J. Comp. Pathol. 2018, 158, 1-5. [CrossRef]

13. Fonseca-Alves, C.E.; Rodrigues, M.M.; de Moura, V.M.; Rogatto, S.R.; Laufer-Amorim, R. Alterations of C-MYC, NKX3.1, and E-cadherin expression in canine prostate carcinogenesis. Microsc. Res. Tech. 2013, 76, 1250-1256. [CrossRef]

14. Palmieri, C.; Lean, F.Z.; Akter, S.H.; Romussi, S.; Grieco, V. A retrospective analysis of 111 canine prostatic samples: Histopathological findings and classification. Res. Vet. Sci. 2014, 97, 568-573. [CrossRef] [PubMed]

15. Fonseca-Alves, C.E.; Kobayashi, P.E.; Rivera-Calderón, L.G.; Laufer-Amorim, R. Evidence of epithelial-mesenchymal transition in canine prostate cancer metastasis. Res. Vet. Sci. 2015, 100, 176-181. [CrossRef] [PubMed]

16. Laufer-Amorim, R.; Fonseca-Alves, C.E.; Villacis, R.A.R.; Linde, S.A.D.; Carvalho, M.; Larsen, S.J.; Marchi, F.A.; Rogatto, S.R. Comprehensive Genomic Profiling of Androgen-Receptor-Negative Canine Prostate Cancer. Int. J. Mol. Sci. 2019, $20,1555$. [CrossRef]

17. Fonseca-Alves, C.D.; Busso, A.F.; Silveira, S.M.; Rogatto, S.R.; Laufer-Amorim, R. Genomic gains in prostatic carcinoma and proliferative inflammatory atrophy in dogs. Cancer Res. 2012, 72, 5260. [CrossRef]

18. Waters, D.J.; Bostwick, D.G. Prostatic intraepithelial neoplasia occurs spontaneously in the canine prostate. J. Urol. 1997, 157, 713-716. [CrossRef]

19. Waters, D.J.; Bostwick, D.G. The canine prostate is a spontaneous model of intraepithelial neoplasia and prostate cancer progression. Anticancer Res. 1997, 17, 1467-1470. [PubMed]

20. Aquilina, J.W.; McKinney, L.; Pacelli, A.; Richman, L.K.; Waters, D.J.; Thompson, I.; Burghardt, W.F.; Bostwick, D.G. High grade prostatic intraepithelial neoplasia in military working dogs with and without prostate cancer. Prostate 1998, 36, 189-193. [CrossRef]

21. Madewell, B.R.; Gandour-Edwards, R.; DeVere White, R.W. Canine prostatic intraepithelial neoplasia: Is the comparative model relevant? Prostate 2004, 58, 314-317. [CrossRef]

22. Wang, W.; Bergh, A.; Damber, J.E. Morphological transition of proliferative inflammatory atrophy to high-grade intraepithelial neoplasia and cancer in human prostate. Prostate 2009, 69, 1378-1386. [CrossRef] [PubMed]

23. Fonseca-Alves, C.E.; Kobayashi, P.E.; Palmieri, C.; Laufer-Amorim, R. Investigation of c-KIT and Ki67 expression in normal, preneoplastic and neoplastic canine prostate. BMC Vet. Res. 2017, 13, 380. [CrossRef] [PubMed]

24. Woenckhaus, J.; Fenic, I. Proliferative inflammatory atrophy: A background lesion of prostate cancer? Andrologia 2008, 40, 134-137. [CrossRef] [PubMed]

25. Leav, I.; Schelling, K.H.; Adams, J.Y.; Merk, F.B.; Alroy, J. Role of canine basal cells in prostatic post natal development, induction of hyperplasia, sex hormone-stimulated growth; and the ductal origin of carcinoma. Prostate 2001, 47, 149-163. [CrossRef]

26. Romanucci, M.; Frattone, L.; Ciccarelli, A.; Bongiovanni, L.; Malatesta, D.; Benazzi, C.; Brachelente, C.; Della Salda, L. Immunohistochemical expression of heat shock proteins, p63 and androgen receptor in benign prostatic hyperplasia and prostatic carcinoma in the dog. Vet. Comp. Oncol. 2016, 14, 337-349. [CrossRef]

27. Akter, S.H.; Lean, F.Z.; Lu, J.; Grieco, V.; Palmieri, C. Different Growth Patterns of Canine Prostatic Carcinoma Suggests Different Models of Tumor-Initiating Cells. Vet. Pathol. 2015, 52, 1027-1033. [CrossRef] 
28. Leis-Filho, A.F.; Fonseca-Alves, C.E. Anatomy, histology, and physiology of the canine prostate gland. In Veterinary Anatomy and Physiology; IntechOpen: London, UK, 2018; pp. 47-67. [CrossRef]

29. Fonseca-Alves, C.E.; Kobayashi, P.E.; Rivera Calderón, L.G.; Felisbino, S.L.; Rinaldi, J.C.; Drigo, S.A.; Rogatto, S.R.; LauferAmorim, R. Immunohistochemical panel to characterize canine prostate carcinomas according to aberrant p63 expression. PLoS ONE 2018, 13, e0199173. [CrossRef]

30. Gupta, A.; Behl, T.; Heer, H.R.; Deshmukh, R.; Sharma, P.L. Mdm2-P53 Interaction Inhibitor with Cisplatin Enhances Apoptosis in Colon and Prostate Cancer Cells In-Vitro. Asian Pac. J. Cancer Prev. 2019, 20, 3341-3351. [CrossRef]

31. McClurg, U.L.; Chit, N.C.T.H.; Azizyan, M.; Edwards, J.; Nabbi, A.; Riabowol, K.T.; Nakjang, S.; McCracken, S.R.; Robson, C.N. Molecular mechanism of the TP53-MDM2-AR-AKT signalling network regulation by USP12. Oncogene 2018, 37, $4679-4691$. [CrossRef]

32. Chopra, H.; Khan, Z.; Contreras, J.; Wang, H.; Sedrak, A.; Zhu, Y. Activation of p53 and destabilization of androgen receptor by combinatorial inhibition of MDM2 and MDMX in prostate cancer cells. Oncotarget 2018, 9, 6270-6281. [CrossRef] [PubMed]

33. Bouali, S.; Chrétien, A.S.; Ramacci, C.; Rouyer, M.; Marchal, S.; Galenne, T.; Juin, P.; Becuwe, P.; Merlin, J.L. P53 and PTEN expression contribute to the inhibition of EGFR downstream signaling pathway by cetuximab. Cancer Gene Ther. 2009, 16, 498-507. [CrossRef]

34. Yang, W.; Wang, K.; Ma, J.; Hui, K.; Lv, W.; Ma, Z.; Huan, M.; Luo, L.; Wang, X.; Li, L.; et al. Inhibition of Androgen Receptor Signaling Promotes Prostate Cancer Cell Migration via Upregulation of Annexin A1 Expression. Arch. Med. Res. 2020. [CrossRef]

35. Nakano, M.; Taura, Y.; Inoue, M. Protein expression of Mdm2 and p53 in hyperplastic and neoplastic lesions of the canine circumanal gland. J. Comp. Pathol. 2005, 132, 27-32. [CrossRef]

36. Mayo, L.D.; Donner, D.B. The PTEN, Mdm2, p53 tumor suppressor-oncoprotein network. Trends Biochem. Sci. 2002, $27,462-467$. [CrossRef]

37. Pant, V.; Lozano, G. Dissecting the p53-Mdm2 feedback loop in vivo: Uncoupling the role in p53 stability and activity. Oncotarget 2014, 5, 1149-1156. [CrossRef]

38. Rivera-Calderón, L.G.; Fonseca-Alves, C.E.; Kobayashi, P.E.; Carvalho, M.; Drigo, S.A.; de Oliveira Vasconcelos, R.; LauferAmorim, R. Alterations in PTEN, MDM2, TP53 and AR protein and gene expression are associated with canine prostate carcinogenesis. Res. Vet. Sci. 2016, 106, 56-61. [CrossRef] [PubMed]

39. Edwards, J.; Krishna, N.S.; Grigor, K.M.; Bartlett, J.M. Androgen receptor gene amplification and protein expression in hormone refractory prostate cancer. Br. J. Cancer 2003, 89, 552-556. [CrossRef] [PubMed]

40. Sun, C.; Dobi, A.; Mohamed, A.; Li, H.; Thangapazham, R.L.; Furusato, B.; Shaheduzzaman, S.; Tan, S.H.; Vaidyanathan, G.; Whitman, E.; et al. TMPRSS2-ERG fusion, a common genomic alteration in prostate cancer activates C-MYC and abrogates prostate epithelial differentiation. Oncogene 2008, 27, 5348-5353. [CrossRef]

41. Attard, G.; Swennenhuis, J.F.; Olmos, D.; Reid, A.H.; Vickers, E.; A’Hern, R.; Levink, R.; Coumans, F.; Moreira, J.; Riisnaes, R.; et al. Characterization of ERG, AR and PTEN gene status in circulating tumor cells from patients with castration-resistant prostate cancer. Cancer Res. 2009, 69, 2912-2918. [CrossRef] [PubMed]

42. Burcham, P.C.; Raso, A.; Henry, P.J. Airborne acrolein induces keratin-8 (Ser-73) hyperphosphorylation and intermediate filament ubiquitination in bronchiolar lung cell monolayers. Toxicology 2014, 319, 44-52. [CrossRef] [PubMed]

43. Ittmann, M.; Huang, J.; Radaelli, E.; Martin, P.; Signoretti, S.; Sullivan, R.; Simons, B.W.; Ward, J.M.; Robinson, B.D.; Chu, G.C.; et al. Animal models of human prostate cancer: The consensus report of the New York meeting of the Mouse Models of Human Cancers Consortium Prostate Pathology Committee. Cancer Res. 2013, 73, 2718-2736. [CrossRef] [PubMed]

44. Committee for the Update of the Guide for the Care and Use of Laboratory Animals. Guide for the Care and Use of Laboratory Animals; The National Academies Press: Washington, DC, USA, 2011.

45. Eble, J.N.; Sauter, G.; Epstein, J.I.; Sesterhenn, I.A. Pathology and Genetics of Tumours of the Urinary System and Male Genital Organs. In Classification of Tumours; WHO, Ed.; WHO: Geneva, Switzerland, 2004; pp. 255-257.

46. Hewitt, S.M.; Baskin, D.G.; Frevert, C.W.; Stahl, W.L.; Rosa-Molinar, E. Controls for immunohistochemistry: The Histochemical Society's standards of practice for validation of immunohistochemical assays. J. Histochem. Cytochem. 2014, 62, 693-697. [CrossRef]

47. Ito, S.; Ohga, T.; Saeki, H.; Nakamura, T.; Watanabe, M.; Tanaka, S.; Kakeji, Y.; Maehara, Y. p53 mutation profiling of multiple esophageal carcinoma using laser capture microdissection to demonstrate field carcinogenesis. Int. J. Cancer 2005, 113, 22-28. [CrossRef]

48. Livak, K.J.; Schmittgen, T.D. Analysis of relative gene expression data using real-time quantitative PCR and the 2(-Delta Delta C(T)) Method. Methods 2001, 25, 402-408. [CrossRef] [PubMed]

49. Rivera-Calderón, L.G.; Fonseca-Alves, C.E.; Kobayashi, P.E.; Carvalho, M.; Vasconcelos, R.O.; Laufer-Amorim, R. p-mTOR, p-4EBP-1 and eIF4E expression in canine prostatic carcinoma. Res. Vet. Sci. 2019, 122, 86-92. [CrossRef]

50. Lai, C.L.; van den Ham, R.; Mol, J.; Teske, E. Immunostaining of the androgen receptor and sequence analysis of its DNA-binding domain in canine prostate cancer. Vet. J. 2009, 181, 256-260. [CrossRef]

51. Kumar, U.; Stecher, G.; Li, M.; Knyaz, C.; Tamura, K. MEGA X: Molecular Evolutionary Genetics Analysis across computing platforms. Mol. Biol. Evol. 2018, 35, 1547-1549. [CrossRef] 